\title{
Komposisi Kimia Tepung Jagung Varietas Unggul Lokal dan Potensinya untuk Pembuatan Mi Jagung menggunakan Ekstruder Pencetak
}

\author{
Tjahja Muhandri, Hamigia Zulkhaiar, Subarna, Budi Nurtama \\ Departemen IImu dan Teknologi Pangan, FATETA - IPB \\ cahyomuhandri@yahoo.com
}

Diterima 28 Maret 2012/ Disetujui 6 Oktober 2012

\begin{abstract}
The objective of this researchis to identify the characteristic of Srikandi Kuning, Bisma, Sukmaraga, Lamuru and Arjuna varieties, and their potentions to be made as wet corn noodle. Corn noodles were processed using forming extruder model MS9, Multifunctional noodle modality machine, Guangdong Henglian Food Machine Co., Ltd., China. Bisma, Lamuru and Arjuna have 27,14-27,68\% of amylose content. The best quality of corn noodle was processed from 100 mesh of corn flour. The result showed that the best processing condition was obtained at moisture of $70 \%$ and adding $2 \%$ of sodium chloride. Under this condition, corn noodles (Bisma, Lamuru and Arjuna varieties) has elongation between 80,32 - 95,43\%, and cooking loss between 5,06 $5,66 \%$.
\end{abstract}

Key words : corn noodle, forming extruder, amylose content

\section{PENDAHULUAN}

Jagung merupakan salah satu sumber karbohidrat yang dapat ditanam di Indonesia. Tepung jagung berpotensi sebagai bahan baku pembuatan mi sehingga dapat mengurangi ketergantungan impor terigu.

Mi jagung memiliki keunggulan berupa warna kuning alami dari jagung sehingga tidak memerlukan bahan tambahan. Mi kuning dari terigu memerlukan pewarna tartrazine. Penelitian tentang proses pembuatan mi dengan bahan baku tepung jagung telah dilakukan oleh beberapa peneliti. Charutigon et al (2007) menggunakan ekstruder pemasak-pencetak ulir tunggal dengan dua buah lubang die berukuran $0,6 \mathrm{~mm}$. Pada kecepatan aliran sekitar $750 \mathrm{gr} / \mathrm{jam}$ (kecepatan ulir ekstruder $50 \mathrm{rpm}$ ) dihasilkan mi (vermicelli) yang dapat diterima oleh panelis terlatih. Pada kecepatan aliran 400-700 gr/jam (kecepatan ulir lebih rendah), vermicelli tidak diteri ma oleh panelis. Cooking loss vermicelli hasil penelitian Charutigon et al (2007) cukup tinggi yaitu 14,2\%. Demikian juga penelitian yang dilakukan Waniska et al (1999) menggunakan ekstruder pencetak, menghasillkan mi yang memiliki cooking loss yang tinggi yaitu di atas $47 \%$.

Tingginya cooking loss pada penelitian Waniska et al (1999) diduga karena adonan tidak cukup mengalami kompresi dan shear sehingga struk tur mi kurang kokoh. Muhandri (2007) membuat mi jagung menggunakan ekstruder pemasak-pencetak ulir tunggal dengan karakteristik ekstruder : (1) rasio screw L/D 30, (2) memiliki 2 buah die berdiameter $2,5 \mathrm{~mm}$ dan (3) dilengkapi pemanas eksternal serta pengatur kecepatan screw ekstruder. Penelitian tersebut menghasilkan mi basah dengan cooking loss yang rendah yaitu $4,88 \%$ dan elongasi yang tinggi yaitu $318,68 \%$. Kondisi proses optimum adalah kadar air tepung jagung $70 \%$ (basis kering), suhu ekstruder $90^{\circ} \mathrm{C}$ dan kecepatan screw ekstruder $130 \mathrm{rpm}$.

Pada penelitian sebelumnya belum ada laporan varietas jagung yang cocok untuk dibuat mi. Namun Tam et al (2004) memberikan karakteristik berupa kandungan amilosa sekitar $28 \%$ yang cocok untuk dibuat bihun dari jagung. Karena itu, untuk menghasilkan mi jagung dengan mutu reologi yang baik perlu dilakukan identifikasi sifat- 
sifat fungsional tepung jagung dan pemilihan varietas jagung sebagai bahan baku tepung jagung.

Tujuan dari penelitian ini adalah : 1) menganalisis komposisi kimia tepung jagung dari lima varietas jagung lokal berwarna kuning, dan 2) pembuatan mi basah jagung dari kelima varietas yang digunakan.

\section{Bahan dan Alat}

\section{METODOLOGI}

Bahan yang digunakan dalam penelitian ini terdiri dari tepung jagung varietas Srikandi Kuning, Bisma, Sukmaraga, Lamuru dan Arjuna ukuran 100 mesh, NaCl, dan air serta bahan - bahan kimia untuk keperluan analisis. Jagung pipil diperoleh dari Balai Penelitian Serealia (DEPTAN) Maros, Sulawesi Selatan.

Alat yang digunakan terdiri dari peralatan untuk analisis proksimat, kadar pati dan kadar amilosa, ekstruder pencetak mi (ekstruder pasta) model MS9, Multifunctional noodle modality machine, Guangdong Henglian Food Machine Co., Ltd., China, pemasak dan texture analyzer TA-XT2i. Ekstruder pasta yang digunakan memiliki ciri-ciri : diameter barrel $3,2 \mathrm{~cm}$, diameter ulir $3,1 \mathrm{~cm}$, kedalaman fligth $0,9 \mathrm{~cm}$, lubang die berjumlah 24 buah dengan diameter masing-masing lubang adalah $1,5 \mathrm{~mm}$. Panjang zona pengumpan $14,0 \mathrm{~cm}$ dan panjang zona kompresi $8,5 \mathrm{~cm}$. Kecepatan ulir ekstruder konstan, yaitu $70 \mathrm{rpm}$.

\section{Pembuatan Tepung Jagung}

Tepung jagung yang baik untuk dibuat mi jagung yaitu tepung jagung yang lolos ayakan 100 mesh (Waniska et al, 1999). Diagram alir pembuatan tepung jagung dapat dilihat pada Gambar 1.

\section{Penelitian Pendahuluan}

Tujuan penelitian pendahuluan ini adalah mendapatkan jumlah air yang harus ditambahkan pada pembuatan $\mathrm{mi}$ basah jagung. Penentuan kadar air adonan dimaksudkan agar didapatkan mi basah jagung yang tidak lengket, plastis dan seragam. Variabel konsentrasi penambahan air terdiri dari kadar air $60 \%, 70 \%, 80 \%$, dan $90 \%$ berdasarkan basis kering tepung jagung. Pada penelitian pendahuluan ini, analisis terhadap mi basah jagung dilakukan melalui pengamatan visual.

Penelitian pendahuluan juga ditujukan untuk melihat perbedaan karakteristik mi basah yang dihasilkan berdasarkan perbedaan ukuran partikel tepung jagung. Untuk melihat perbedaan karakteristik mi jagung dari beberapa ukuran tepung jagung, digunakan varietas Bima dengan ukuran tepung lolos ayakan 60 mesh, lolos 80 mesh dan lolos 100 mesh.

\section{Pembuatan Mi Basah Jagung}

Pembuatan mi jagung diawali dengan penimbangan bahan. Sodium klorida sebanyak $2 \%$ (dari berat tepung) dilarutkan dalam air. Air yang ditambahkan ke dalam adonan sebanyak $70 \%$ dari berat tepung. Diagram alir pembuatan mi basah jagung disajikan pada Gambar 2. Analisis yang dilakukan terhadap mi basah jagung meliputi elongasi dan cooking loss. 


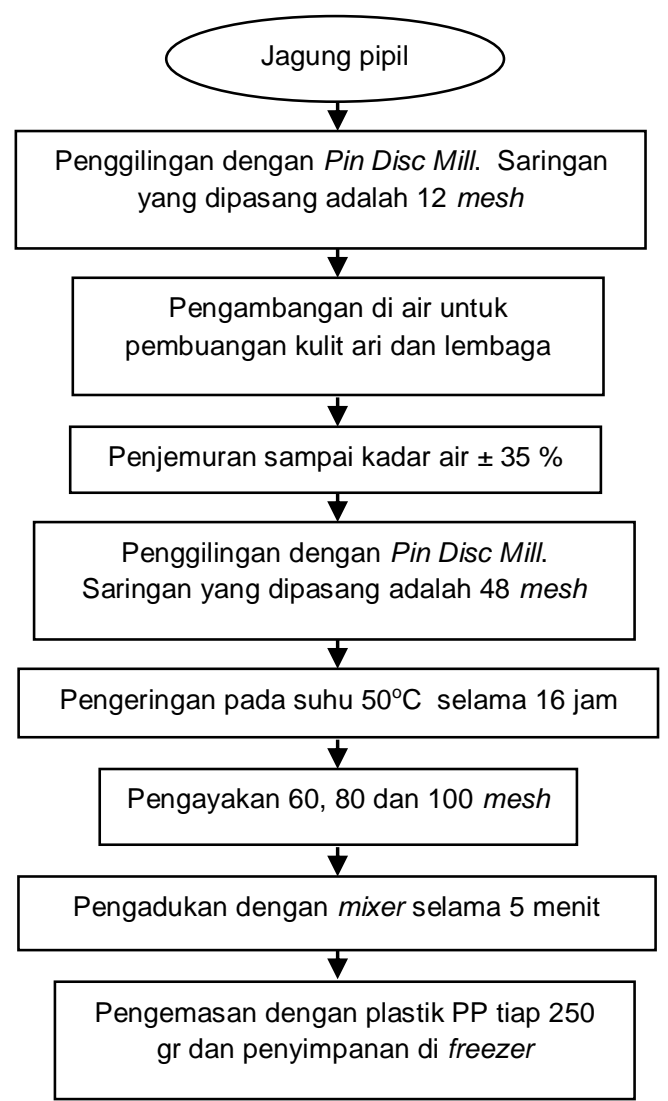

Gambar 1. Proses pembuatan tepung jagung

\section{Karakterisasi Tepung Jagung}

Analisis karakterisasi tepung jagung meliputi kadar air metode oven (AOAC, 1995), kadar abu (AOAC, 1995), kadar lemak metode soxhlet (SNI 01-2891-1992), kadar protein metode mikro kjeldahl (AOAC, 1995), kadar karbohidrat by difference (AOAC, 1995), kadar pati metode luff schoorl (Sudarmadji et.al., 1997) dan kadar amilosa metode IRRI (AOAC, 1995).

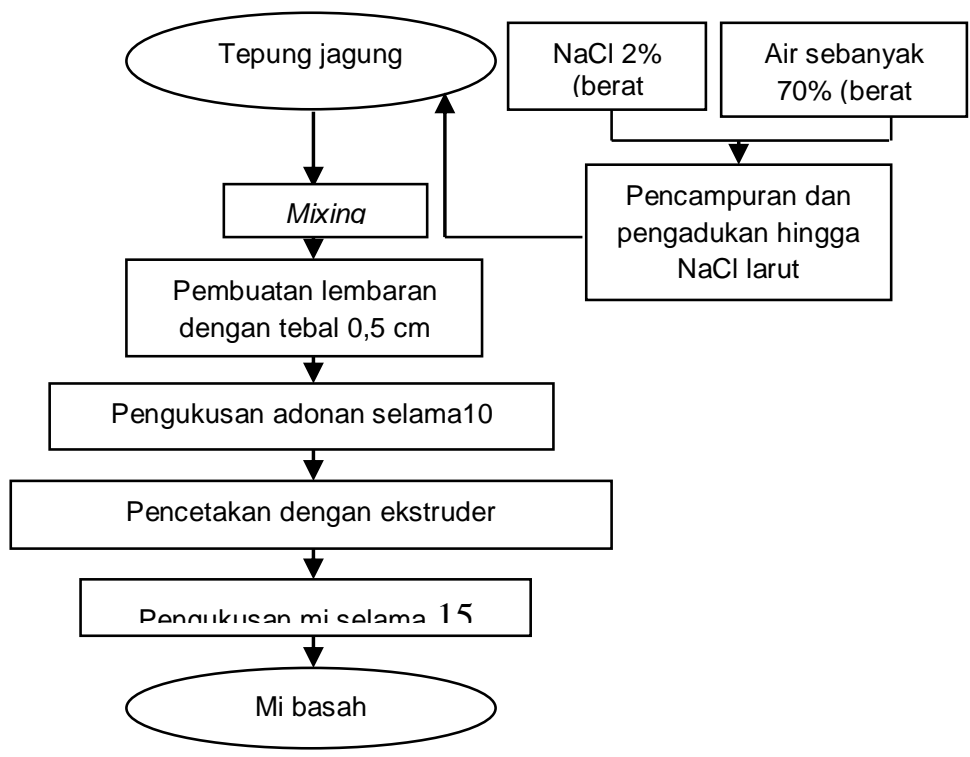

Gambar 2. Diagram alir pembuatan mi basah jagung 


\section{Analisis Mi Jagung \\ Elongasi}

Analisis mi jagung meliputi Analisis Persen Elongasi menggunakan Texture Analyzer, dimana sampel dililitkan pada probe dengan jarak pro be sebesar $2 \mathrm{~cm}$ dan kecepatan probe $0,3 \mathrm{~cm} / \mathrm{s}$. Persen elongasi dihitung dengan rumus :

Elongasi $(\%)=\underline{\text { waktu putus sampel }(\mathrm{s}) \times 0,3 \mathrm{~cm} / \mathrm{s}} \times 100 \%$

$$
2 \mathrm{~cm}
$$

\section{Cooking Loss (CL)}

Penentuan cooking loss dilakukan dengan cara merebus sekitar 5 gram mi dalam $150 \mathrm{ml}$ air selama 3 menit lalu mi ditiriskan. Mi kemudian dikeringkan pada suhu $100^{\circ} \mathrm{C}$ sampai beratnya konstan, lalu ditimbang kembali. Mi yang lain sebanyak kira-kira 5 gram diukur kadar airnya (data kadar air digunakan untuk menghitung berat kering sampel). Cooking loss dinyatakan sebagai :

$C L(\%)=\underline{A-B} \times 100 \%$

$A$

A : Berat kering sampel sebelum direbus

B : Berat kering sampel sesudah direbus

\section{HASIL DAN PEMBAHASAN}

\section{Pembuatan Tepung Jagung}

Pemilihan varietas jagung didasarkan pada penelitian Syuryawati et al. (2005) yang menyatakan bahwa Indonesia memiliki enam varietas jagung unggul yaitu Arjuna, Bisma, Lamuru, Sukmaraga, Srikandi Kuning dan Srikandi Putih. Varietas Srikandi Putih tidak digunakan karena mi basah jagung yang diinginkan dalam penelitian ini berwarna kuning alami dari tepung jagung itu sendiri.

Penggilingan biji jagung menjadi tepung jagung pada prinsipnya adalah proses pemisahan endosperma jagung dari bagian lain dan mengecilkan ukurannya (Hoseney, 1998). Dengan teknik penepungan di atas, rendemen tepung dari kelima varietas sekitar $50 \%$. Alat pin disc mill bekerja dengan mekanisme impact sehingga tidak mampu menghancurkan horny endosperm. Tepung jagung yang lolos ayakan 100 mesh lebih didominasi oleh floury endosperm.

\section{Komposisi Kimia Tepung Jagung}

Komposisi kimia tepung jagung dari lima varietas yang digunakan disajikan pada Tabel 1. Kadar protein tepung jagung dari lima varietas yang digunakan dalam penelitian ini sesuai dengan hasil penelitian Lorenz dan Karel (1991), yang menyebutkan rata-rata protein dari endosperma jagung adalah $8,0 \%$.

Kandungan lemak tepung jagung yang berkisar antara 1,62 - 1,85\% memiliki nilai yang lebih besar dari yang disampaikan Lorenz dan Karel (1991) yaitu sebesar 0,8\% pada bagian endosperma. Proses pemisahan lembaga dan tip cap (bagian biji jagung yang banyak mengandung lemak) belum sempurna karena pemisahannya menggunakan pengambangan manual. Masih ada bagian lembaga dan tip cap yang tertinggal atau menempel pada grit dan turut tergiling.

Kandungan amilosa kelima varietas jagung berada pada kisaran 23,06\%$27,26 \%$. Kadar amilosa tertinggi dimiliki oleh tepung jagung varietas Lamuru $(27,26 \%)$ dan yang terendah dimiliki oleh tepung jagung varietas Srikandi Kuning (23,06\%). Kandungan amilosa ini berada di bawah kisaran amilosa jagung normal seperti yang 
diungkapkan oleh Bellizt dan Grosch (1999) yaitu sebesar 28\%. Namun jika dikaitkan dengan pernyataan Tam et al (2004), yang menyebutkan bahwa kisaran amilosa jagung normal adalah 27 - $29 \%$, varietas Bisma, Lamuru dan Arjuna merupakan jagung normal.

Perbedaan jumlah amilosa ini dapat disebabkan oleh perbedaan varietas jagung. Kandungan amilosa yang cukup merupakan satu hal yang diharapkan dalam pembuatan mi non-terigu karena memiliki daya ikat yang lebih kuat (Kim et al, 1996).

Tabel 1. Karakteristik Tepung Jagung menurut Varietas

\begin{tabular}{llcccccc}
\hline No. & Varietas & Kadar & Kadar & Kadungan Kimia (\%) & Kadar & Kadar & Kadar \\
& & air & abu & protein & lemak & pati & amilosa \\
\hline 1. & Srikandi Kuning & 12,04 & 0,59 & 9,12 & 1,69 & 71,69 & 23,06 \\
2. & Bisma & 12,14 & 0,62 & 8,84 & 1,73 & 72,40 & 27,59 \\
3. & Sukmaraga & 12,02 & 0,73 & 9,22 & 1,81 & 75,10 & 23,67 \\
4. & Lamuru & 10,95 & 0,83 & 9,20 & 1,85 & 74,96 & 27,68 \\
5. & Arjuna & 12,55 & 0,55 & 8,96 & 1,62 & 74,92 & 27,14 \\
\hline
\end{tabular}

\section{Penelitian Pendahuluan}

Berdasarkan hasil pengamatan secara visual, karakterisitik mi basah jagung dengan variabel kadar air dapat dilihat pada Tabel 2. Berdasarkan pengamatan secara visual, terlihat bahwa karakteristik mi yang paling optimum dengan penambahan air pada adonan sebesar $70 \%$ (berat tepung). Pada kadar air tersebut mampu menghasilkan mi yang elastis, tidak lengket, dan warna seragam, walaupun adonan agak sulit dibentuk lembaran (Gambar 3.a.).

Tabel 2. Pengaruh Kadar Air terhadap Adonan dan Mi yang Dihasilkan

\begin{tabular}{|c|c|c|}
\hline $\begin{array}{l}\text { Kadar Air } \\
\text { (\%) }\end{array}$ & Karakteristik Adonan & Karakteristik Mi \\
\hline 60 & $\begin{array}{l}\text { Adonan terlalu kering, adonan sulit } \\
\text { dibentuk lembaran (patah-patah), } \\
\text { adonan dapat dicetak menjadi mi. }\end{array}$ & $\begin{array}{l}\text { Mi yang dihasilkan lurus, tidak } \\
\text { lengket, dan elastis, beberapa helai } \\
\text { mi masih ada yang bewarna putih. }\end{array}$ \\
\hline 70 & $\begin{array}{l}\text { Adonan semi basah, adonan agak } \\
\text { sulit dibentuk lembaran dan dipotong } \\
\text { kotak-kotak. }\end{array}$ & $\begin{array}{l}\text { Mi yang dihasilkan lurus, tidak } \\
\text { lengket, warna mi seragam, dan } \\
\text { elastic }\end{array}$ \\
\hline 80 & $\begin{array}{l}\text { Adonan basah, adonan mudah } \\
\text { dibentuk lembaran dan dipotong } \\
\text { kotak-kotak. }\end{array}$ & $\begin{array}{l}\text { Mi yang dihasilkan lengket dan agak } \\
\text { elastis }\end{array}$ \\
\hline 90 & $\begin{array}{l}\text { Adonan terlalu basah dan lengket, } \\
\text { adonan mudah dibentuk lembaran } \\
\text { dan dipotong kotak-kotak. }\end{array}$ & $\begin{array}{l}\text { Mi yang dihasilkan sangat lengket, } \\
\text { basah, dan mudah putus. }\end{array}$ \\
\hline
\end{tabular}

Berdasarkan hasil pengukuran cooking loss, tepung jagung dengan ukuran 100 mesh menghasilkan nilai cooking loss paling rendah (Tabel 3). Tepung jagung ukuran 60 mesh menghasilkan mi dengan nilai cooking loss terbesar. Hasil ini sesuai dengan hasil penelitian Waniska et al (1999) yang menyatakan bahwa tepung jagung yang memiliki ukuran lebih kecil, lebih baik untuk dibuat mi jagung. 
Tabel 3. Pengaruh Ukuran Tepung terhadap Cooking Loss Mi Basah Jagung

\begin{tabular}{cc}
\hline Ukuran Tepung (Lolos Ayakan Mesh) & Cooking Loss (\%) \\
\hline 60 & 8,92 \\
80 & 6,29 \\
100 & 5,89 \\
\hline
\end{tabular}

Tingkat cooking loss, menurut Wang et al (1999) tergantung pada tingkat gelatinisasi dan kekuatan struktur gel dari mi. Tingkat gelatinisasi dipengaruhi oleh penetrasi panas dan air ke dalam granula (Srichuwong, 2006) sedangkan kekuatan struktur gel dipengaruhi oleh pembentukan ikatan hidrogen antar pati ketika terjadi retrogradasi (Charutigon et al, 2007). Menurut Nishita dan Bean (1982), pada granula tepung yang berukuran besar, sebagian besar pati di dalam tepung jagung masih terjebak butiran tepung, sehingga pati sulit mengalami gelatinisasi.

\section{Karakteristik Mi Basah Jagung}

Berdasarkan hasil penelitian pendahuluan, tepung jagung yang digunakan yaitu tepung yang lolos ayakan 100 mesh. Kadar air adonan sebesar 70\%. Natrium klorida $(\mathrm{NaCl})$ ditambahkan pada adonan tepung jagung untuk memperkuat adonan dan mengurangi penyerapan air. $\mathrm{NaCl}$ yang digunakan sebanyak $2 \%$, hal ini disesuaikan dengan pernyataan $\mathrm{Wu}$ et al., (2006) bahwa penggunaan $\mathrm{NaCl}$ disarankan tidak lebih dari $2 \%$. Penggunaan $\mathrm{NaCl}$ di atas $3 \%$ dapat merusak reologi mi. Karakteristik mi basah jagung dari kelima varietas disajikan pada Tabel 4.

Tabel 4. Karakteristik Mi Basah Jagung

\begin{tabular}{clcc}
\hline No. & Varietas Jagung & Elongasi (\%) & Cooking Loss $(\%)$ \\
\hline 1. & Srikandi Kuning & $58,70^{\mathrm{a}}$ & $6,92^{\mathrm{b}}$ \\
2. & Bisma & $80,32^{\mathrm{b}}$ & $5,06^{\mathrm{a}}$ \\
3. & Sukmaraga & $64,31^{\mathrm{a}}$ & $6,54^{\mathrm{b}}$ \\
4. & Lamuru & $95,43^{\mathrm{bc}}$ & $5,41^{\mathrm{a}}$ \\
5. & Arjuna & $82,93^{\mathrm{b}}$ & $5,66^{\mathrm{a}}$ \\
6. & Mi Basah Terigu & $107,35^{\mathrm{c}}$ & $5,59^{\mathrm{a}}$ \\
\hline
\end{tabular}

Keterangan : huruf yang sama menunjukkan tidak berbeda nyata pada taraf $p<0,05$

Mi basah jagung memiliki elongasi berkisar antara 58,70\% (varietas Srikandi Kuning) sampai $95,43 \%$ (varietas Lamuru). Nilai elongasi mi basah jagung dari kelima varietas masih berada di bawah elongasi mi basah terigu yaitu 107,35\%. Cooking loss mi basah jagung berkisar antara 5,06\% (varietas Bisma) sampai 6,92\% (varietas Srikandi Kuning). Nilai cooking loss mi basah jagung tidak berbeda nyata $(p<0,05)$ dengan cooking loss mi basah terigu.

Mi basah jagung dari kelima varietas memiliki cooking loss yang lebih tinggi dan elongasi yang lebih rendah jika dibandingkan dengan penelitian Muhandri (2007). Hal ini diduga terjadi karena perbedaan tekanan yang diterima adonan selama proses pencetakan mi jagung. Muhandri (2007) menggunakan ekstruder pemasak-pencetak, dimana adonan tepung jagung masuk ke dalam ekstruder dalam keadaan mentah sehingga mudah mengalir melewati ekstruder. 

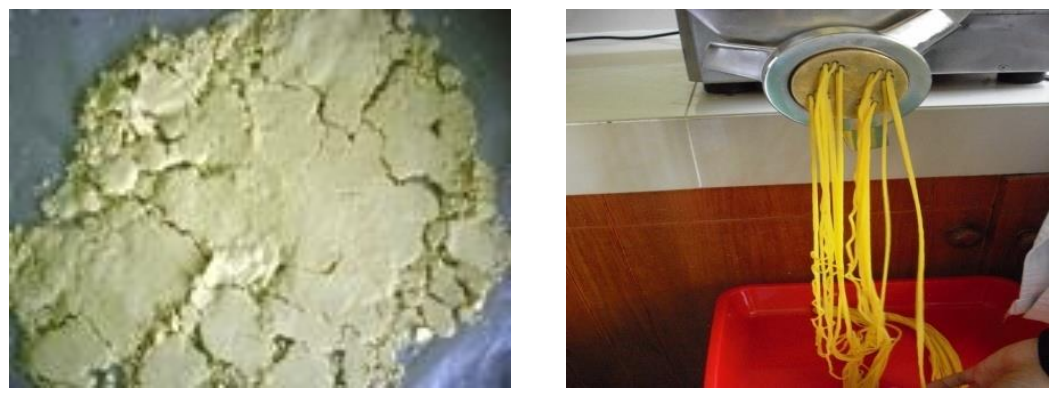

Gambar 3. (a) Adonan sebelum dikukus, (b) Proses pencetakan mi basah jagung

Pada penelitian ini digunakan ekstruder pencetak, dimana adonan tepung jagung telah dikukus sehingga tidak mudah mengalir karena berbentuk gumpalan yang kohesif dan agak lengket, sehingga ruang antara ulir dan laras (barrel) tidak selalu dalam keadaan penuh. Kondisi tersebut menyebabkan tingkat kompresi yang kurang. Tingkat kompresi pada adonan akan menentukan struktur, kepadatan, daya ikat antar partikel bahan dan tekstur produk termasuk elongasi.

Pada kondisi proses dengan tekanan shear yang tidak cukup, granula tepung jagung masih terlihat sebagai individu yang tidak menyatu dengan yang lain. Granula pati tidak terpisah secara sempurna dari granula tepung. Ketika mi jagung mengalami retrogradasi pada saat pendinginan, ikatan hidrogen yang terbentuk tidak terjadi pada semua molekul pati, tetapi hanya terbatas pada molekul pati yang terpisah dari granula tepung jagung saja. Pada kondisi proses optimum menggunakan ekstruder pemasakpencetak, adonan menerima tekanan shear dan mengalami gelatinisasi yang cukup, sehingga ikatan hidrogen antar granula pati terjadi dengan baik.

Berdasarkan karakteristik utama mi basah yaitu elongasi yang tinggi dan cooking loss yang rendah, maka varietas jagung yang lebih sesuai untuk dibuat menjadi mi basah jagung adalah varietas Bisma, Lamuru dan Arjuna. Ketiga varietas ini memiliki kandungan amilosa yang tergolong sebagai jagung normal (Bellizt dan Grosch, 1999; Tam et al., 2004).

Hasil penelitian ini juga sejalan dengan hasil penelitian Tam et al., (2004) yang menyatakan bahwa bihun jagung yang baik dihasilkan dari pati jagung yang memiliki kadar amilosa antara $27-29 \%$. Dari pati jagung dengan amilosa yang tinggi $(40-60,8 \%)$ akan dihasilkan bihun jagung yang keras dan dari pati jagung dengan amilosa rendah $(0,2-3,8 \%)$ akan dihasilkan bihun jagung yang kurang baik yaitu patah-patah ketika dimasak.

\section{SIMPULAN}

Karakteristik utama tepung yang diperlukan dalam pembuatan mi basah jagung adalah kandungan amilosa. Varietas Bisma, Lamuru dan Arjuna tergolong sebagai jagung normal, sedangkan varietas Srikandi Kuning tergolong sebagai jagung rendah amilosa. Mi basah jagung terbaik diperoleh dari tepung jagung yang berukuran kecil (lolos ayakan 100 mesh). Formula yang digunakan untuk pembuatan mi basah jagung adalah kadar air adonan $70 \%$ (berat kering) dan penambahan natrium klorida $2 \%$ (berat tepung). Varietas jagung yang sesuai untuk dibuat mi basah yaitu Bisma, Lamuru dan Arjuna, dengan karakteristik elongasi antara 80,32 - 95,43\% dan karakteristik cooking loss antara 5,06 $5,66 \%$. 


\section{DAFTAR PUSTAKA}

AOAC. 1995. Offical Methods of Analysis of the Association Analytical Chemistry. AOAC International, Maryland.Belitz HD, Grosch W. 1999. Food Chemistry. Springer, Berlin.

Charutigon C, Jintana J, Pimjai N, Vilai R. 2007. Effects of processing conditions and the use of modified starch and monoglyseride on some properties of extruded rice vermicelli. Swiss Society of Food Science and Technology, LWT 41 (2008) 642651.

Honesey RC. 1998. Principle of Cereal Science and Technology, $2^{\text {nd }}$ edition. American Association of Cereal Chemist Inc., St. Paul, Minnesota, USA.

Kim YS, Dennis PW, James HL, Patricia B. 1996. Suitability of Edible Bean and Potato Starches fo Starch Noodles. www.aaccnet.org/cerealchemistry/ backissues/1996/73 302.pdf. [22 Mei 2007].

Lorenz KJ, Karel K. 1991. Handbook of Cereal Science and Technology. Marcell Dekker, Inc. Basel.

Muhandri T. 2007. Karakteristik Reologi Mie Jagung yang Dibuat dengan Proses Ekstrusi Pemasak-Pencetak. Laporan Penelitian Dosen Muda. Institut Pertanian Bogor. Bogor.

Nishita K, Bean MM. 1982. Grinding methods : their impact on rice flour properties. Cereal Chem 59:46-49.

Tam LM, Corke H, Tan WT, Li J, Collado LS. 2004. Production of Bihon-type Noodles from Maize Starch Differing in Amylose Content. American Association of Cereal Chemists, Inc.

Wang N, Bhirud PR, Sosulski, FW, Tyler RT. 1999. Pasta-like product from pea flour by twin-screw extrusion. J Food Sci. 64 (4), 671-677.

Waniska RD, Yi T, Lu J, Xue Ping L, Xu W, Lin H. 1999. Effects of preheating temperature, moisture, and sodium metabisulfite content on quality of noodles prepared from maize flour or meal. J Food Sci. Technol 5: $339-346$. 